Cooper, P. D. (1957). J. gen. Microbiol. 17, 335-352

\title{
Paths of Phosphate Transfer in Normal Chick Embryo Cells and in Cells Infected with Vesicular Stomatitis Virus
}

\author{
BY P. D. COOPER* \\ Division of Biology, California Institute of Technology, Pasadena, California, U.S.A.
}

SUMMARY: The paths of phosphate transfer were compared in normal and vesicular stomatitis virus-infected chick embryo cell monolayers during one-step virus growth. Phosphate entered the normal cell via an inorganic pool in reversible equilibrium with external phosphate, and passed to large-molecule phosphate from this pool or from organic acid-soluble phosphate. During the latent and exponential release periods of virus infection there was no detectable slowing or stimulation of the rate of gain of ${ }^{32} \mathrm{P}$ by acid-soluble inorganic and organic phosphates ( $\mathrm{AI}$ and $\mathrm{AO}$ ), lipid phosphate (LP), ribonucleic acid (RNA) and other phosphate fractions until uptake ceased in nearly all fractions about half-way through exponential release. Negligible $P$ or ${ }^{32} P$ entered or left deoxyribonucleic acid (DNA) in normal or infected cells in this system. Before and during exponential release there was no detectable lysis of nuclei, mitochondria or microsomes (examined after isolation), and no detectable loss of ${ }^{32} \mathrm{P}$ from AI, AO, LP, RNA or DNA, except for a late 30-50\% decrease in the ${ }^{32} \mathrm{P}$ of the sucrose-soluble RNA of disrupted cells. This could be a secondary effect (i.e. onset of cell death) rather than an essential stage of virus growth. Gross lysis was evident in all fractions $20 \mathrm{hr}$. after infection, with the exception of the acid-soluble inorganic fraction not in reversible equilibrium with the medium.

Viral nucleic acid synthesis should be reflected in some changes in phosphate metabolism. A study of such changes should provide information on virus growth complementary to direct examination of infected cells (e.g. by the electron microscope) which is likely to show stages of maturation rather than of nucleic acid replication. Chemical changes should tell more than relative assays of infective unit content when examining subcellular fractions, as such assays only count subcellular particles with attached mature virus rather than the number or nature of virus attached; non-adsorption of released mature virus to free subcellular particles may not be a good control. Furthermore, this overlooks possible viral replication in the 'soluble' cytoplasmic portion, as infective virus, being particulate, will always be removed from this fraction.

The vesicular stomatitis (VS) virus-chick embryo cell system can satisfy certain criteria for chemical study of the effects of virus growth (Cooper, 1957 a). Such a study is presented below, where phosphate metabolism is compared in normal and infected cells during the latent and exponential release periods.

There is little data on normal phosphate pathways available for intact animal cells in vitro with all cells equally accessible to the medium, and the chick cell system, although definitely limited metabolically, has some tech-

* Present address : Virus Culture Laboratory, M.R.C. Laboratories, Carshalton, Surrey. 
nical advantages for such a study over the living animal. In particular, one knows the specific activity of the external phosphate, and one can trace phosphate pathways from the specific activities of increments of homogeneous phosphate fractions (Mitchell \& Moyle, 1953). Some information on the entry of inorganic phosphate is presented separately (Cooper, 1957b).

\section{METHODS}

Preparation of chick cell monolayers, virus stocks, virus assay, media and the method for the one-step growth curve on monolayers are described by Cooper (1957a).

Type of experiments described. In most experiments, one infected and one control monolayer plus media were harvested at intervals to give one-step growth curves lasting less than $24 \mathrm{hr}$. In the first 2-3 days, non-infected monolayers lost negligible amounts of soluble or particulate RNA or DNA, assimilated ${ }^{32} \mathrm{P}$ maximally, remained normal microscopically and grew virus well so that negligible cell material was lost or changed by 'non-specific' death, lysis or detachment.

Methods of studying $\boldsymbol{P}$ pathrways. The words 'exchange', 'gain' or 'loss' are used to define the phosphate transfers, rather than the ambiguous 'turnover'. Three types of experiment were used.

(a) 'Specific activities of increments.' The relative specific activities (' $R$ values'), i.e. the ratios of the observed values of ${ }^{32} \mathbf{P} / \mathbf{P}$ to that value to be expected at complete equilibration (Mitchell \& Moyle, 1953), of some SchmidtThannhauser fractions were determined at intervals during uptake of ${ }^{32} \mathbf{P}$ by cells. Then, if a fraction $\mathbf{A}$ is homogeneous the specific activity of any small sample passing from $\mathbf{A}$ into another fraction $B$ ("specific activity of the increment of B') will have the specific activity of A (Mitchell \& Moyle, 1953). Thus, knowing the specific activity of the increment of $B$, the true precursor pool to $B$ is known if the only alternatives have sufficiently different specific activities. In practice this method is limited, since few pools are homogeneous and a single specific activity of an increment rests on four assays so that errors are magnified. It was only used for normal pathways.

(b) 'Gain' experiments. ${ }^{32} \mathrm{PO}_{4}$ was added with the virus (i.e. to monolayers $20 \mathrm{hr}$. old) and the increase with time of the ${ }^{32} \mathrm{P}$ of each fraction was followed in control and infected cells during one-step virus growth.

(c) 'Loss' experiments. ${ }^{32} \mathrm{PO}_{4}$, added to the Petri dishes with the cell suspensions, was incorporated overnight at $37^{\circ}$. After $20 \mathrm{hr}$. the medium was removed, the cell layers washed three times with warm medium, virus added for one-step growth and the progressive loss of the total ${ }^{32} \mathbf{P}$ of each fraction was followed. The ${ }^{32} \mathrm{P}$ added did not exceed $1 \mu \mathrm{c} / \mathrm{ml}$. medium.

Cells were fractionated after 'gain' and 'loss' experiments by the SchmidtThannhauser, sucrose and sucrose $+\mathrm{CaCl}_{2}$ cell homogenization, and citric acid methods described below. The two complementary experiments proved quite informative for $\mathbf{P}$ pathways in control cells, particularly for differentiating those fractions which were in reciprocal exchange from those which were not. 
They should also show virus-induced lysis, or stimulation of incorporation or exchange, which if big enough should affect the total ${ }^{32} \mathrm{P}$ of any fraction in either or both 'gain' or 'loss'.

Harvesting of cells. The medium was frozen at intervals for virus, $\mathrm{P}$ or ${ }^{32} \mathrm{P}$ assay, and the cells resuspended from the unwashed monolayer with $5 \mathrm{ml}$. $25 \mathrm{mg} . / \mathrm{ml}$. trypsin $\left(10 \mathrm{~min}\right.$. at $\left.37^{\circ}\right)$ were quantitatively removed, washed once with $5 \mathrm{ml}$. cold phosphate buffer saline (PBS) and frozen for SchmidtThannhauser separation, or washed once with $5 \mathrm{ml}$. cold $\mathbf{0 . 2 5} \mathrm{M}$-sucrose for homogenization or citric acid extraction.

Sucrose homogenization. The method of Hogeboom, Schneider \& Striebich (1953) was used. The washed cells were quantitatively transferred to a PotterElvehjem glass homogenizer in sufficient $(0.15 \mathrm{ml}$.) $0.25 \mathrm{~m}$-sucrose to fill the space between pestle and container without overflowing and without air bubbles. The pestle was rotated by an electric motor at an arbitrary constant speed while the container was held in a cradle; the tension was kept constant for all samples by supporting the cradle with stretched rubber bands. Each sample contained $2 \times 10^{7}$ cells, and the cells were always kept at ice-water temperature. The rotation time (usually $60 \mathrm{sec}$.) allowed at least $95 \%$ cell rupture (haemocytometer count). Recovery of nuclei, counted in $\mathbf{0 \cdot 1} \mathbf{1}$-citric acid containing $1 \mathrm{mg}$. $/ \mathrm{ml}$. crystal violet, was $75-90 \%$ in sucrose alone, but after addition of $0.0018 \mathrm{M}-\mathrm{CaCl}_{2}$ according to Hogeboom et al. (1953) was always more than $95 \%$. The ruptured suspension was quantitatively removed and centrifuged for $10 \mathrm{~min}$. at $1500 \mathrm{rev} . / \mathrm{min}$. to sediment remaining cells and nuclei, either over a $1 \mathrm{ml}$. layer of $0.34 \mathrm{M}$-sucrose (giving excellent separation) or directly, and washed once with $2 \mathrm{ml} . \mathbf{0 \cdot 2 5} \mathrm{m}$-sucrose. The pooled supernatant fluids were centrifuged for $10 \mathrm{~min}$. at $10,000 \mathrm{rev} . / \mathrm{min}$. in the Spinco rotor No. 40, and the opaque sediment ('mitochondria') washed once with $2 \mathrm{ml}$. $0 \cdot 25 \mathrm{M}$-sucrose. The supernatant fluids, again pooled, were then

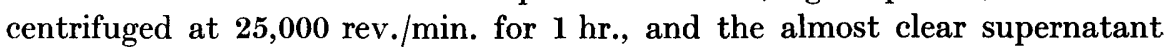
removed ('soluble fraction'). The translucent pellet ('microsomes') was resuspended in $1 \mathrm{ml} . \mathbf{0} \cdot 25 \mathrm{M}$-sucrose without washing. The contamination in the nuclear fraction (calculated from theoretical dilution by washing) was $<3 \%$ of the cytoplasm using sucrose alone, but $30 \%$ of its radioactivity may be due to the $5 \%$ of cells remaining unbroken (better preparations were not possible because of the relative fragility of nuclei). The addition of $0.0018 \mathrm{M}$ $\mathrm{CaCl}_{2}$ to the sucrose, however, gave very good recoveries of nuclei substantially uncontaminated with whole cells, but in this case mitochondria were not separable from microsomes. Therefore, similar experiments were performed in presence or absence of $\mathrm{CaCl}_{2}$ to examine particularly either nuclei, or mitochondria plus microsomes respectively. The mitochondrial fraction contained $<0.5 \%(\mathrm{v} / \mathrm{v})$ of the microsome + soluble fractions, and the microsomes $2-4 \%$ $(\mathrm{v} / \mathrm{v})$ of the soluble fraction.

Citric acid fractionation. This method (Sanford, Earle, Evans, Waltz\&Shannon, 1951) was as follows. To the pellet of sucrose-washed cells $2 \mathrm{ml}$. of $0 \cdot 1 \mathrm{M}$-citric acid were added and the tubes immersed in a $37^{\circ}$ water bath with periodic vigorous pipetting. After $1 \mathrm{hr}$. the tubes were centrifuged for $10 \mathrm{~min}$. at 
$1500 \mathrm{rev} . / \mathrm{min}$., the supernatant fluid removed and $2 \mathrm{ml}$. fresh citric acid added. Then after $1 \mathrm{hr}$. at $37^{\circ}$ the tubes were kept at $2^{\circ}$ overnight, centrifuged, the supernatant fluids pooled ('citric acid soluble' fraction) and the sediments ('nuclei') resuspended in citric acid for assay. Recovery of nuclei (haemocytometer count with $0 \cdot 1 \%$ crystal violet) was $80 \%$, intact cells were $<2 \%$.

Modified Schmidt-Thannhauser separation method. This was developed from Mitchell \& Moyle (1953), Davidson, Frazer \& Hutchison (1949), Davidson \& Smellie (1952) and Katchman \& Fetty (1955), and is presented schematically in the diagram. Some abbreviations and definitions, mostly derived from Mitchell \& Moyle (1953) are:

'Hot acid hydrolysis' (Katchman \& Fetty, 1955)=addition of 1/10 vol. $10 \mathrm{~N}-\mathrm{HCl}$, immersed in boiling water for $15 \mathrm{~min}$.

' $\mathrm{Mg}$ pptn.=addition to $\frac{1}{2} \mathrm{ml}$. sample of $0 \cdot 1 \mathrm{ml} .5 \% \mathrm{MgCl}_{2}+0 \cdot 1 \mathrm{ml} \cdot \mathbf{0} \cdot \mathbf{2} \mathrm{M}$ phosphate (as carrier) $+\mathbf{0} \cdot 1 \mathrm{ml}$. conc. ammonia solution (sp.gr. 0.880). After $16 \mathrm{hr}$. at $2^{\circ}$, the crystals were sedimented in the centrifuge.

'Acid-soluble' = soluble after 30 min. treatment with $10 \%(\mathrm{w} / \mathrm{v})$ trichloroacetic acid (TCA) at $2^{\circ}$.

' $\mathrm{mI}$ ' = inorganic phosphate of the medium.

' $\mathrm{mAO}$ ' = organic acid-soluble phosphates present in medium but derived from cells.

The remaining fractions are defined as being present in the cell only.

'AI' = acid-soluble inorganic orthophosphate.

' $\mathrm{AO}$ ' = acid-soluble organic phosphate stable to 'hot acid hydrolysis'.

' 7 'P' = acid-soluble phosphate converted to AI by 'hot acid hydrolysis' ('seven-minute phosphate', Katchman \& Fetty, 1955).

'LMP' = acid-insoluble phosphate (large molecule phosphate).

'LP' = hot-methanol-soluble phosphate (lipid phosphate).

' $\mathbf{R N A}$ ' = acid-insoluble phosphate transformed to AO by warm alkali, and regarded as predominantly derived from ribonucleic acid phosphate.

' $\mathrm{PP}$ ' = acid-insoluble phosphate transformed to AI by warm alkali, and including phospho-protein phosphate.

' $\mathbf{L} \mathbf{M}^{\prime} \mathbf{P}$ ' = acid-insoluble phosphate transformed to ' $\gamma^{\prime} \mathbf{P}$ ' by warm alkali.

'DNA' = essentially residual phosphate, mostly derived from deoxyribonucleic acid phosphate, but containing some residual RNA and PP phosphates.

In one 'gain' experiment (Fig. 2c) RNA was extracted from the cells after harvesting by hot $10 \%(\mathrm{w} / \mathrm{v}) \mathrm{NaCl}$ according to Davidson \& Smellie (1952). Extract and residue were subsequently fractionated by the Schmidt-Thannhauser procedure.

Efficiency of the fractionation procedures. It is acknowledged (e.g. Hogeboom et al. 1953) that the current methods of fractionating cells into their particulate components are unsatisfactory, and it is clear from the above procedures that, for example, 'mitochondria' will contain a small proportion of microsomes and nuclei, by their aggregation or disintegration, even if each fraction be completely homogeneous with respect to particle size. 'Mitochondrial' and 'microsomal' preparations have been observed to contain at least two 
(Laird, Nygaard, Ris \& Barton, 1953) or three (Novikoff, Podber, Ryan \& Noe, 1953) types of components, respectively, and the 'sucrose-soluble' and citric-acid soluble fractions will clearly contain any extractable substances which properly belong to a particulate fraction. The present work is therefore

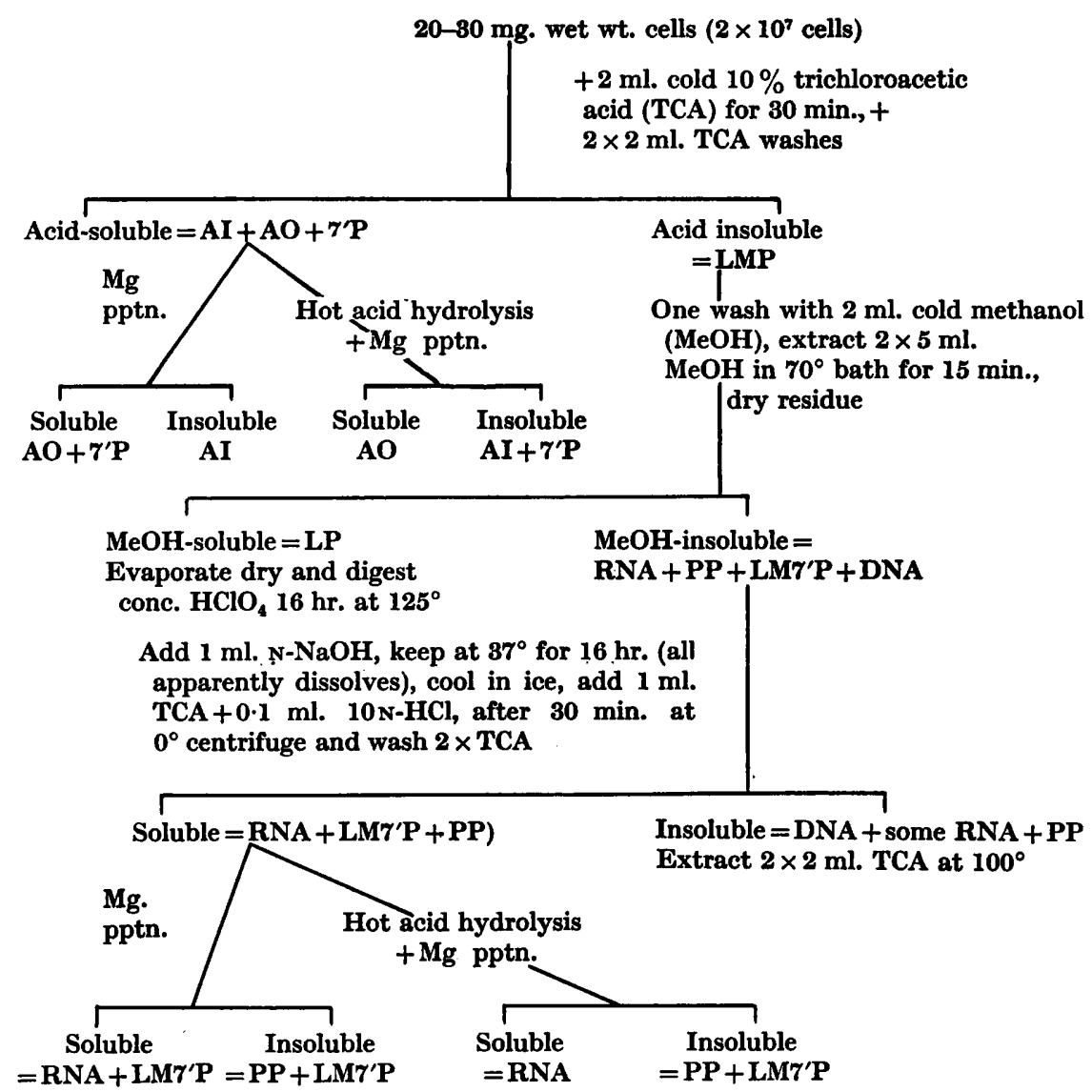

Scheme of modified Schmidt-Thannhauser separation method. The names of the fractions (e.g., 'RNA') are used by virtue of other workers' results with this method, and serve as definitions rather than as indications that these fractions have been checked chemically by the author.

obliged to define the fractions obtained solely in terms of their mode of preparation. Except for the nuclei, whose purity can be partly observed, much reserve must be attached to interpreting the fractions in terms of their function in the intact cell.

Estimation of $\mathbf{P}$ and ${ }^{32} \mathrm{P}$. Phosphate was determined as inorganic phosphate after $10 \mathrm{hr}$. digestion at $120^{\circ}$ with $0.5 \mathrm{ml} . \mathrm{HClO}_{4}$ by the method of Fiske \& SubBarow (1925). ${ }^{32} \mathrm{P}$ was determined after drying the neutralized samples on $1 \mathrm{~cm}$. copper planchettes by means of a Nuclear Instrument and Chemical Corp. (Chicago) automatic end-window Geiger counter with window thickness c. $0.5 \mathrm{mg}$. $/ \mathrm{cm} .{ }^{2}$. All samples were counted for at least 1000 counts and correction was made where necessary for radioactive decay and background counts 
( $<16 \mathrm{cts} . / \mathrm{min}$.). Samples were always counted where self-absorption and coincidence were negligible $\left(<10 \mathrm{mg} . / \mathrm{cm} .{ }^{2}\right.$ and $<5000 \mathrm{cts} . / \mathrm{min}$. respectively).

Preparation of fully-labelled cells. Twenty-five fertile eggs were inoculated via the yolk sac with $20 \mu \mathrm{c}$. of ${ }^{32} \mathrm{P}$ in $\mathbf{0 . 2} \mathrm{ml}$. of Earle's saline (ES) before incubation. Only 6 embryos survived to 10 days, while the remainder were bacteriologically sterile but only $1 \mathrm{~cm}$. long (fertility rate of un-inoculated eggs was $80 \%$ ). At 10 days the full-size embryos were removed, cells prepared and allowed to form as monolayers overnight in the usual way in nonradioactive medium. After $20 \mathrm{hr}$. the monolayers were washed twice with medium, and the usual one-step growth 'loss' experiment performed, the cells being harvested and fractionated by the Schmidt-Thannhauser procedure. Virus production was, if anything, somewhat higher than average.

\section{RESULTS}

Normal pathways of phosphate transfer in monolayers $20-40 \mathrm{hr}$. old

At least five main chemical fractions appeared to exist in each of at least four main subcellular fractions. Few, if any, of the fractions were homogeneous. An attempt is made to trace the broad phosphate pathways among the major chemical (Schmidt-Thannhauser) fractions in the cell as a whole, and from $\mathbf{P}$ and ${ }^{32} \mathbf{P}$ contents of centrifugal fractions at particular times certain further details may be deduced. The interpretations summarized in Fig. 1 are given at this stage to help presentation of the evidence.

Source and function of $\mathrm{AI} .{ }^{32} \mathrm{PO}_{4}$ passed from the medium into $\mathrm{AI}$ much faster than into other fractions, while no net increase of the AIP occurred (Table 1); the transfer had largely ceased after 4-5 hr. (Fig. 2) when the specific activities of $\mathrm{AI}$ and $\mathrm{mI}$ were substantially equal (Table 1). The implied equal loss of non-radioactive $P$ should be large and rapid and was not found as a gain in any organic fraction, but the reverse loss of $\mathrm{AI}{ }^{32} \mathrm{P}$ back to $\mathrm{mI}$ occupied the same period of time (Fig. 3) so that evidently at least some of AI is in reversible equilibrium with $\mathrm{mI}$. However, only $30 \%$ (Table 3 ) to $50 \%$ (Fig. 3) of the AI ${ }^{32} \mathbf{P}$ gained in overnight incubation, and equivalent to about half the AIP of the cells (from Tables 1 and $2 a$ ) equilibrates in this way, showing that $\mathrm{AI}$ is not homogeneous. The two AI fractions can be called 'reversible' $\left(\mathrm{AI}_{\mathrm{R}}\right)$ and 'irreversible' $\left(\mathrm{AI}_{\mathrm{I}}\right)$ and appear from these data to have similar specific activities. $\mathbf{A I}_{\mathrm{I}}$ can only be distinguished from $\mathbf{A I}_{\mathrm{R}}$ as ${ }^{32} \mathrm{P}$ after equilibration with an excess of non-radioactive MIP, when (Fig. 3 and Table $3 a$ ) the $\mathrm{AI}_{\mathrm{I}}{ }^{32} \mathrm{P}$ was twice the highest value of the $\mathrm{AO}{ }^{32} \mathrm{P}$, while the total $\mathrm{AI}_{\mathrm{I}}$ $P$ must be considerably less than the total AOP (from Table 1, assuming that $\mathbf{A I}_{\mathrm{I}} \mathbf{P} \leqslant$ half $\left.\left[\mathbf{A I}_{\mathrm{R}}+\mathbf{A I}_{\mathrm{I}}\right]\right)$. This large difference in specific activity between $A O$ and $A I_{I}$ only allows that $A I_{I}$ is rapidly derived from $A I_{R}$ or $\mathrm{mI}$ at a rate similar to the exchange into $\mathrm{AI}_{\mathrm{R}}$, and not from $\mathrm{AO}$ or large molecule phosphate (LMP). Its stability in the 'loss' experiments, even after $20 \mathrm{hr}$., suggests that it is not an intermediary in $\mathbf{P}$ metabolism. It may be a very acid-labile polyphosphate; its stability to the presumably enzymic lysis in infected cells up to 20 hr. (Fig. 3) does not suggest an organic phosphate. 


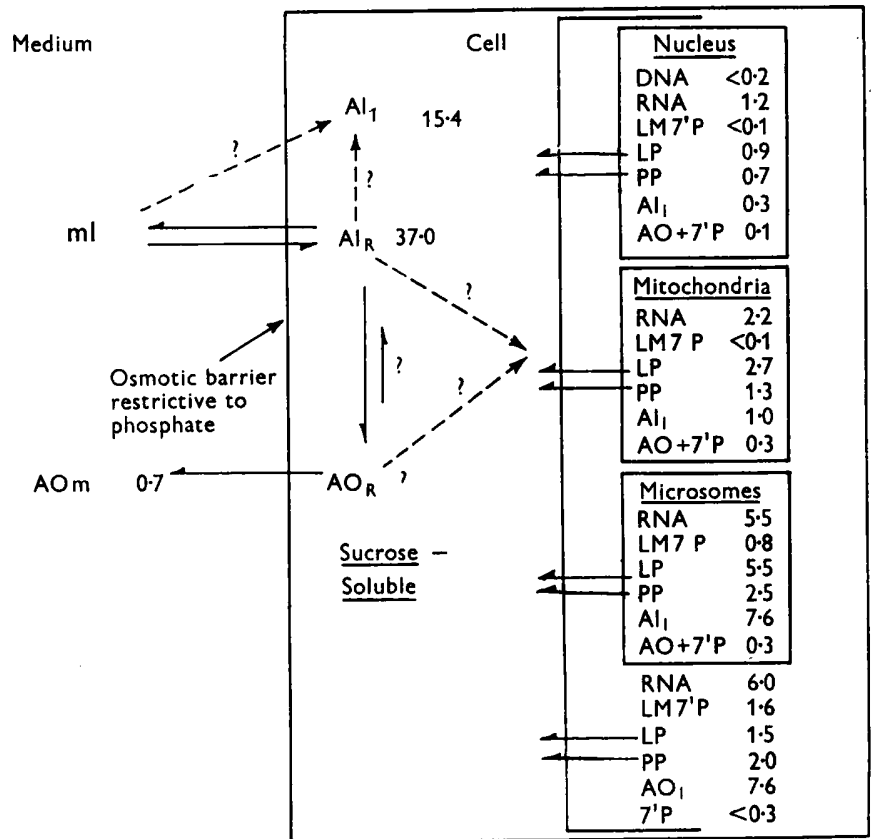

Fig. 1. Diagram of suggested phosphate pathways. Evidence for the restrictive osmotic barrier is given elsewhere (Cooper, 1957b). Figures represent distribution of ${ }^{32} \mathbf{P}$ after a 'loss' experiment of $7 \mathrm{hr}$. (data from Table $3 a$ ) calculated as percentage of total ${ }^{32} \mathrm{P}$ in washed cells at commencement of 'loss'.
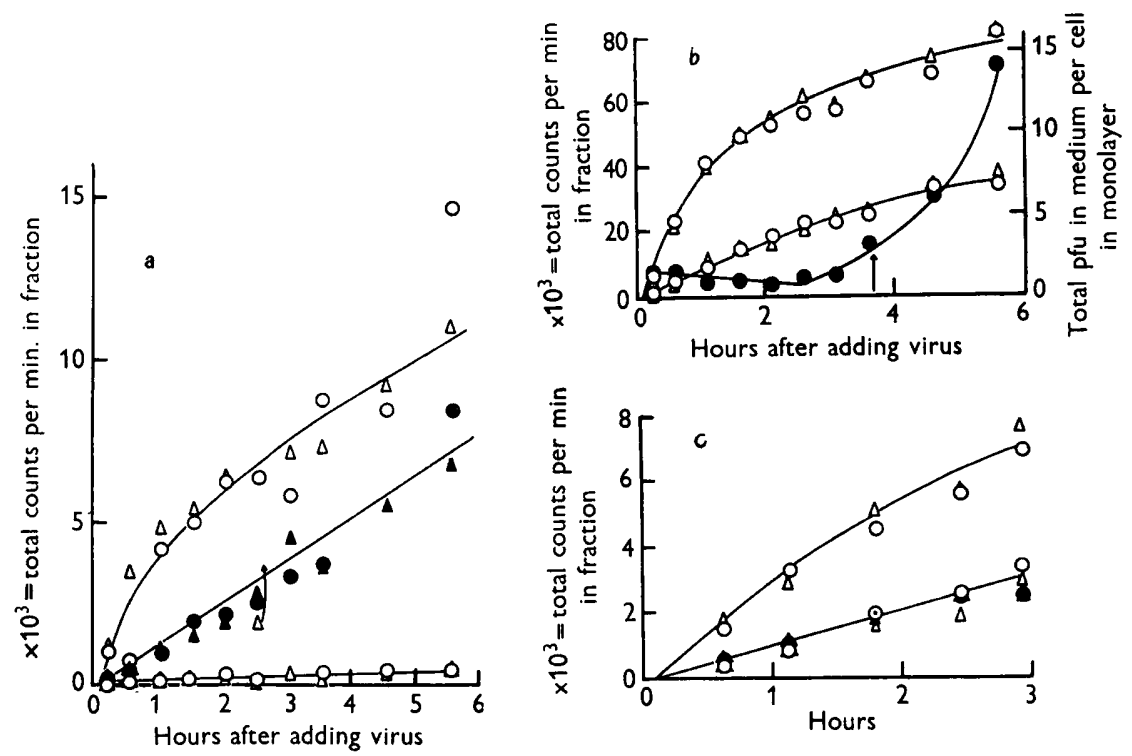

Fig. 2. A ${ }^{32} \mathbf{P}$ 'gain' experiment ( $a$ and $b$ ) followed by Schmidt-Thannhauser (S-T) fractionation of whole cells. Circles represent control, and triangles infected samples. ${ }^{32} \mathrm{P}$ was added $5 \mathrm{~min}$. after addition of virus. In $(a)$, the topmost and lowest curves $(0, \Delta)$ represent RNA and DNA respectively, and the middle curve $(\bullet, \Delta)$ LP. In $(b)$, the upper and lower curves $(O, \triangle)$ represent $A I$ and $A O$ respectively, and $(\bullet)=$ virus release. Multiplicity of adsorption $=2-3$. The arrow $(b)$ indicates the end of the latent period obtained by extrapolation of a logarithmic plot. (c) Represents a separate experiment performed identically with $(a)$ and $(b)$. The upper curve in $(c)$ is total S-T RNA; the lower is the result of extraction with hot $10 \% \mathrm{NaCl}$ followed by separation of S-T RNA from the extract $(O, \Delta)$ and the residue $(\mathbf{0}, \Delta)$. 
Table 1. 'Relative specific activities' $(R)$, total phosphorus ( $\mu$ g. $P$ ) and total ${ }^{32} P$ (counts per $\min =c / m$ ) contents of Schmidt-Thannhauser phosphate fraction during ${ }^{32} P$ incorporation by chick-cell monolayers maintained in $\mathrm{ES} / 4 \%$ horse serum at $37^{\circ}$ in a $\mathrm{CO}_{2}$-air mixture

${ }^{32} \mathrm{PO}_{4}$ was first added to the once-washed monolayers $20 \mathrm{hr}$. after their formation, and each sample represents one monolayer $\left(2 \times 10^{7}\right.$ cells).

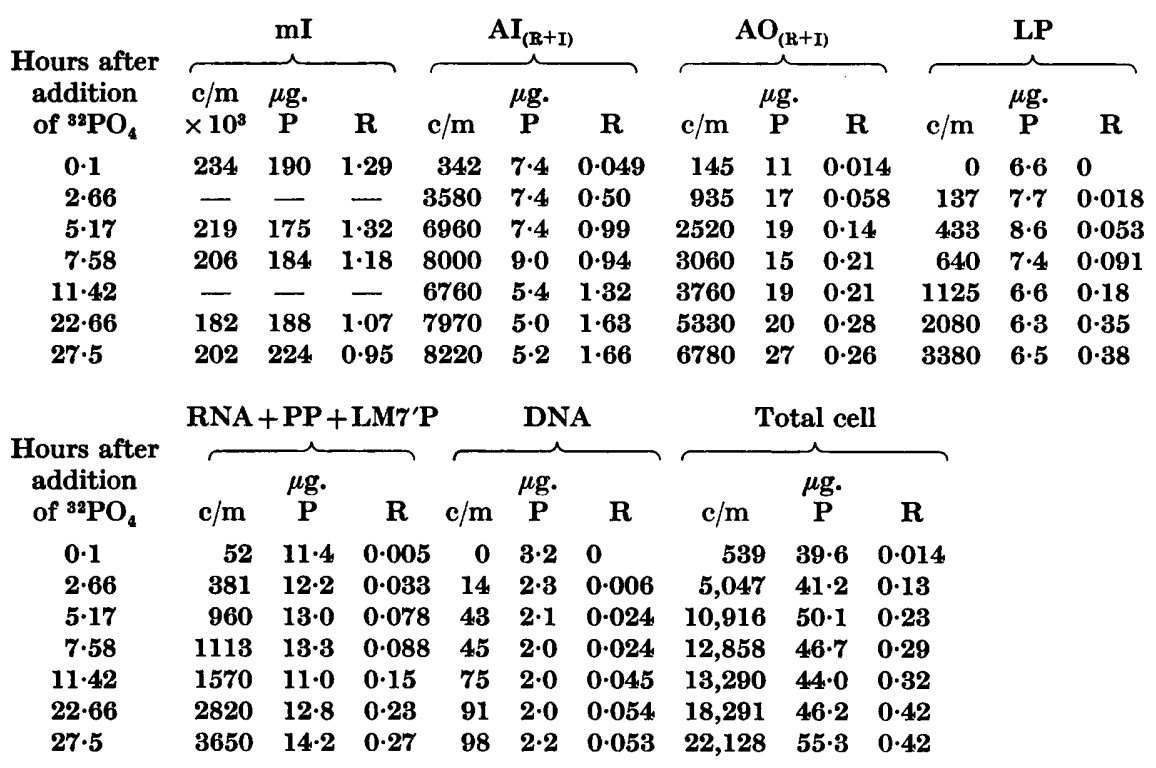

In the 'loss' experiment of Fig. 3 it can be seen that the gain in $\mathrm{mI}{ }^{32} \mathrm{P}$ is slightly greater than the drop of $\mathbf{A I}_{R}$, which is unexpected as some $\mathbf{A I}_{R}$ is lost to AO and LMP by synthesis; it is probably due to the small loss from LP, PP and possibly AO noticeable in Table 2 and Fig. 3.

As with Micrococcus pyogenes (Staphylococcus aureus) (Mitchell \& Moyle, 1953) $\mathbf{A I}_{\mathbf{R}}$ here is probably a pool supplying most of the cellular $\mathbf{P}$; the $\mathbf{R}$ values of the increase of AO and LMP mentioned in the next sections suggests that AI is an intermediary between $\mathrm{mI}$ and organic phosphate. The way in which this pool is retained by the cell is discussed separately (Cooper, 1957b).

Source and function of $A O$. The increment in $\mathrm{AO}$ between the mean values for $0-8 \mathrm{hr}$. in Table 1 (1662 cts./min. and 15.5 $\mathrm{g}$. P) and 11-28 hr. (5290 cts./ min. and $22 \mu \mathrm{g} . P$ ) is $3628 \mathrm{cts}$. $/ \mathrm{min}$. and $6.5 \mu \mathrm{g}$. $P$, so that its $R$ value is 0.59 ; this amount of phosphorus at such a specific activity is clearly only derivable largely from $\mathrm{mI}$ or AI, whose specific activity is about unity between these times. Some $\mathbf{P}$ may be derived from the relatively unlabelled LMP by lysis or acid-lability. This same figure of 0.59 , rather than a value nearer one, and the low specific activities of the initial increments make it likely that most AO derives from AI rather than $\mathrm{mI}$.

In some 'gain' experiments the $\mathbf{R}$ values of the increments of $\mathrm{AO}$ were much higher than $1(2-3)$, indicating a high rate of replacement of $\mathrm{P}$ by ${ }^{32} \mathrm{P}$; 
while LMP was increasing and was low in ${ }^{32} \mathrm{P}$ this could be due to $\mathrm{AO}$ acting as intermediary between AI and LMP, or by reciprocal exchange between AI and AO. Such an exchange is not suggested by the loss experiment of Fig. 3, where the drop in $\mathrm{AO}^{32} \mathrm{P}$ is not reciprocated by a gain in $\mathbf{L M}{ }^{32} \mathbf{P}$ but by a gain

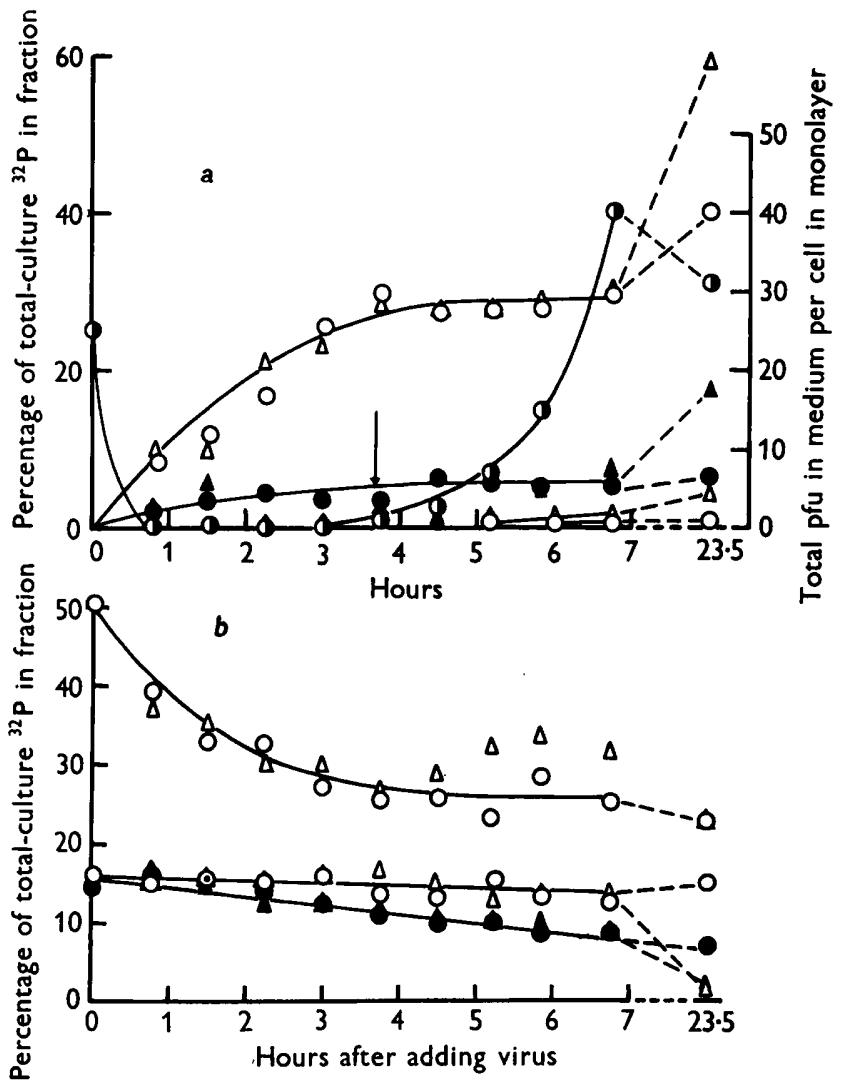

Fig. 3. A ${ }^{32} \mathrm{P}$ 'loss' experiment followed by Schmidt-Thannhauser fractionation of whole cells. Circles represent control and triangles infected samples. (a) Shows changes in the medium and $(b)$ changes in the cells. In $(a)$, the upper $(O, \Delta)=\mathbf{A I}$, the lower $(O, \Delta)=L M P,(O, \Delta)=A O$ and $(O)=$ virus release. In $(b)$, the upper $(O, \Delta)=\mathbf{A I}$, the lower $(O, \Delta)=$ RNA, and $(\bullet, \Delta)=A O$. Multiplicity of adsorption $=2-3$. The arrow indicates the end of the latent period obtained by extrapolation of a logarithmic plot. Cellular lipid phosphate and phospho-protein behaved similarly to RNA + LM7'P. 'DNA' is not given, as this was uniformly $0 \cdot 3-1 \cdot 2 \%$ in both control and infected cells at all times.

in $\mathrm{mAO}{ }^{32} \mathrm{P}$. On the other hand, much less $\mathrm{AO}{ }^{32} \mathrm{P}$ was lost to the medium in the experiment of Table $3 a$. The stability of about half the $\mathrm{AO}^{32} \mathrm{P}$ even after $23 \mathrm{hr}$. in this experiment $\left(\mathrm{AO}_{\mathrm{I}}\right)$ suggests that not all the $\mathrm{AO}$ is available as a metabolic pool.

It is possible that at least some AO is a part of LMP easily separated by TCA rather than, like inorganic phosphate (Cooper, 1957b) free as small molecules in the cell; in this case the particular acid-labile LMP is restricted to the sucrose-soluble fraction (Table $\mathbf{3} a$ ). 
It is interesting that the bulk of the $P$ accumulates in the AO (Table 1), and is therefore reminiscent of Micrococcus pyogenes in absence of nitrogen source (Mitchell \& Moyle, 1953); it is as though the major limitation in the $\mathbf{P}$ syntheses of this system occurs at the stage of incorporation into LMP, particularly DNA (see below). However, this appears to be no deterrent to virus growth.

Source of $L P$ and $R N A+P P+7^{\prime} P$. It is difficult to indicate the sources of these fractions because of the presence of components which are able to equilibrate with AI, particularly in the LP and PP fractions (Table 2), and which therefore produce the high $\mathbf{R}$ values of increments characteristic of high exchange rates. This is particularly so for the specific activity of the mean increment between the first half $(0-7 \mathrm{hr}$.) and the second half of the experiment of Table 1, and was even more noticeable if either serum or both serum and glucose were omitted, when marked lysis of LMP occurred. On the other hand, the $\mathbf{R}$ values of the early increments (when the cells were in better condition) of LP and RNA + PP + 7'P were all low, suggesting that the more stable portions of these fractions (particularly RNA) are derived from AO rather than AI or $\mathrm{mI}$. The evidence, however, is not good for this; it is unsatisfactory to base any estimation of the source of RNA P on the specific activities of heterogeneous groups of substances, such as ' $\mathrm{AO}$ ' and ' $\mathrm{RNA}$ ', rather than the individual nucleotides presumed to be concerned. It is clear from the low activity of DNA that RNA $P$ cannot mainly be derived from DNA P. It is noteworthy that the exchange rate of LP is much lower than that of Micrococcus pyogenes (Mitchell \& Moyle, 1953), where LP may be concerned with phosphate uptake mechanisms.

Source of $D N A$. This cannot be determined from these experiments, since very little DNA was synthesized under the conditions used. It is quite likely that the bulk of the ${ }^{32} \mathrm{P}$ observed in the ' $\mathrm{DNA}$ ' fraction is due to the contaminating residue of RNA left by the somewhat inefficient alkaline hydrolysis (except in Table 2), and the scatter frequently present in 'DNA' ${ }^{32} \mathrm{P}$ supports this. It should be noted that the lack of DNA incorporation is probably due to the large number of cells added to each plate $\left(2 \times 10^{7}\right)$, as less than this number can be seen to increase in numbers.

\section{Comparison of $\boldsymbol{P}$ metabolism of normal and virus-infected cells}

As the $\mathbf{R}$ values of increments are too inaccurate to detect small changes, the complementary 'gain' and 'loss' experiments are compared during one-step growth. Stimulation, blockage or reversal of the numerous $\mathbf{P}$ pathways by virus infection might be found by various fractionations.

Schmidt-Thannhauser fractionation of whole cells. The 'gain' experiments (Fig. 2) showed that VS infection had no detectable effect during the latent and early release phases on ${ }^{32} \mathbf{P}$ uptake in $\mathrm{AI}, \mathrm{AO}+\boldsymbol{7}^{\prime} \mathbf{P}, \mathbf{L P}, \mathbf{R N A}+\mathbf{P P}$ or 'DNA' fractions; no effect in the bulk RNA fraction was found when it was extracted with $10 \% \mathrm{NaCl}$ (Fig. 2c) by the method of Davidson \& Smellie (1952). AI equilibration with $\mathrm{mI}$ was unaffected during 'loss' experiments (Fig. 3, Table 2) (see also Cooper, 1957b) and so was total DNA. A barely 
significant increase in AI about the end of the latent period (Fig. 3) may be derived from the LMP and particularly the RNA + LM $7^{\prime} \mathrm{P}$ fraction (Table $2 a$ ). After $23 \mathrm{hr}$. the ${ }^{32} \mathrm{P}$ of the infected cells was nearly all in the medium, mostly as inorganic and acid-soluble organic phosphates. There was a very significant increase in medium LMP (Fig. 3) which coincided with virus release; the $\mathbf{A I}_{\mathrm{I}}$ was not lysed. The use of fully labelled cells (Table 2) takes into account fractions (such as the DNA) which are not fully labelled by incorporation into monolayers as in Fig. 3.

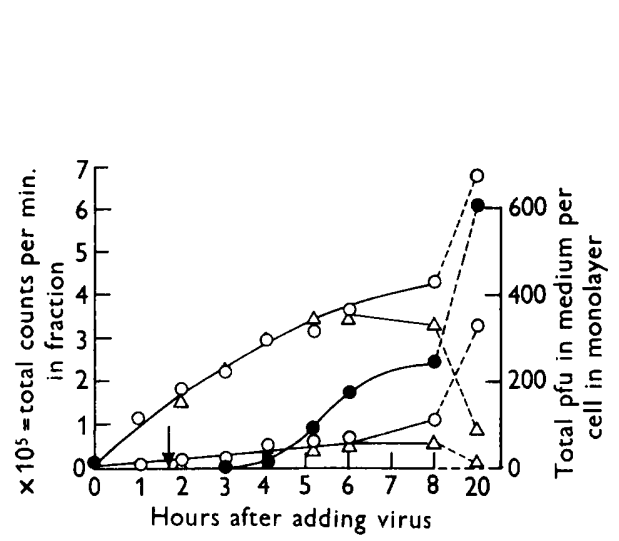

Fig. 4

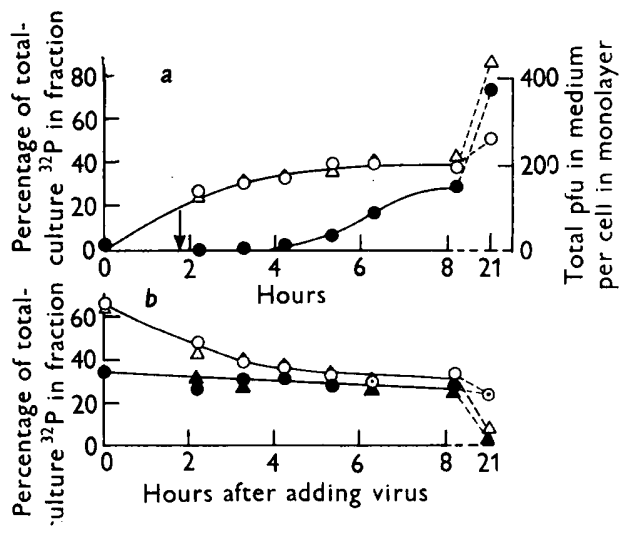

Fig. 5

Fig. 4. A ${ }^{32} \mathbf{P}$ 'gain' experiment followed by cell fractionation by the citric acid method. $(O)=$ virus release. Open circles represent control and triangles infected samples, the upper curve of which shows the citric acid-soluble fraction and the lower the nuclei. The arrow indicates the end of the latent period obtained from extrapolation of a logarithmic plot. Multiplicity of adsorption =5-6.

Fig. 5. A ${ }^{32} \mathbf{P}$ 'loss' experiment followed by cell fractionation by the citric acid method. Circles represent control and triangles infected samples. (a) shows virus release (O) and release of ${ }^{32} \mathrm{P}$ to the medium. (b) shows the citric-acid soluble fraction $(O, \Delta)$ and the nuclei $(\boldsymbol{\Delta}, \Delta)$. The arrow indicates the end of the latent period obtained from extrapolation of a logarithmic plot. Multiplicity of adsorption =5-6.

0.1 M-Citric acid fractionation. This method in my hands separated an impure nuclear fraction (cell-free but with attached wisps of cytoplasm) and a citricacid soluble fraction, comprising the acid-soluble nuclear components (small, Table 3) plus the rest of the cell. 'Gain' experiments employing this fractionation (Fig. 4) showed that total $\mathbf{P}$ uptake ceased in both fractions during the exponential release period, while the complementary 'loss' experiment (Fig. 5) showed no big loss from nuclei or cytoplasm as a whole. Increased ${ }^{32} \mathrm{P}$ release into the medium during this period was equivocal but was marked after $24 \mathrm{hr}$., both nuclei and soluble fractions being much depleted in both experiments. Unstained nuclei isolated towards the end of exponential virus release were microscopically identical with controls, the nuclear membrane showing no gross damage.

Potter-Elvehjem homogenization. Cells were either homogenized in $\mathbf{0 \cdot 2 5}$ M-sucrose, giving good separation of mitochondria and microsomes but allowing easier rupture of nuclei (Hogeboom et al. 1953); or in 0.25 $\mathrm{M}$-sucrose +0.0018 


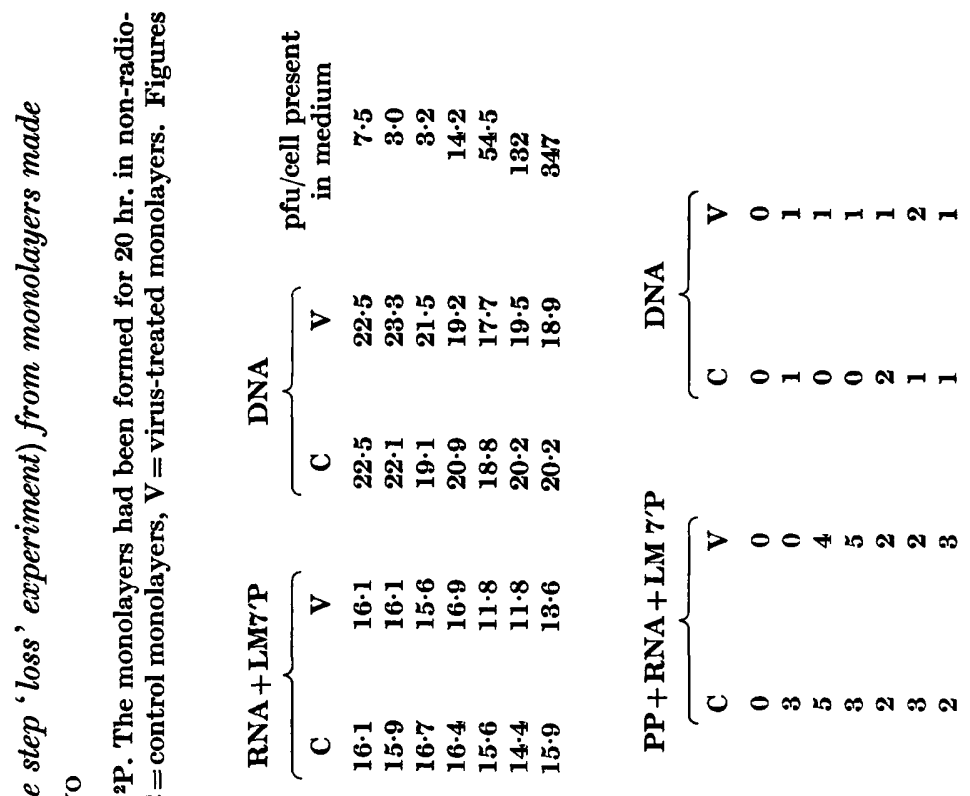

है :

을

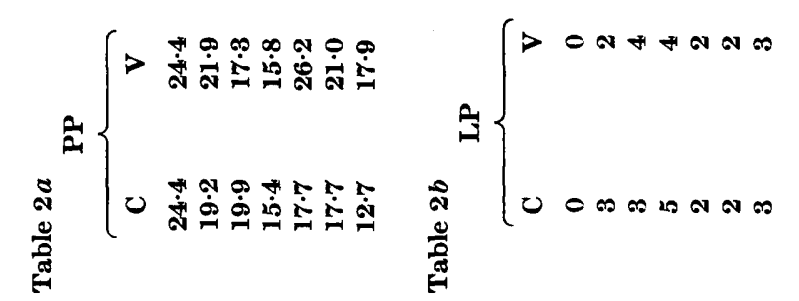

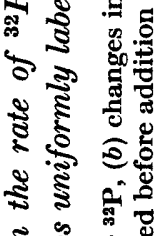

s:

웡

ธิ ถิำ

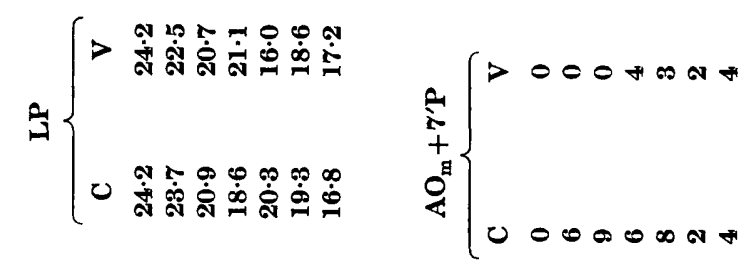

.

है. s

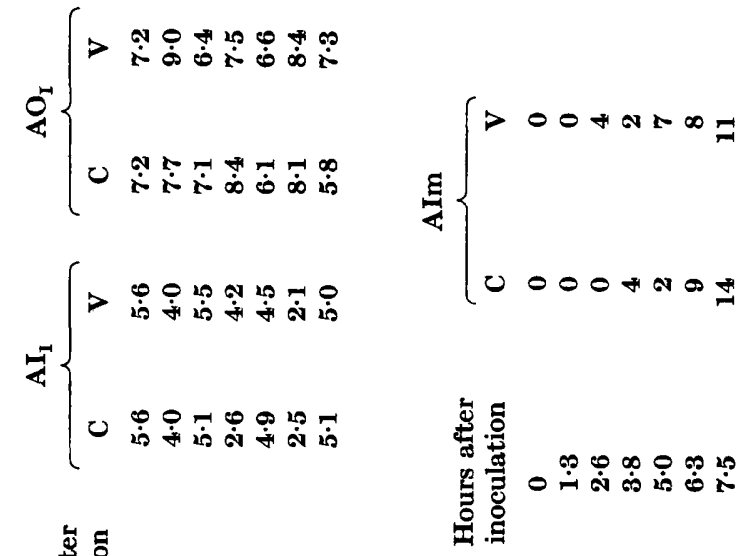

ำ

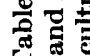

워

क्ष

ङ छे है

20

จ

a 11

苋 
$\mathrm{M}-\mathrm{CaCl}_{2}$, in which nuclei are less fragile but mitochondria and microsomes are not separable. The gain experiment in Ca-free sucrose (Fig. 6) showed that ${ }^{32} \mathbf{P}$ uptake by microsomes and soluble fraction was halted at the beginning of or during exponential virus release, although mitochondria were not affected. In this experiment the whole cells present in the nuclear fraction masked any changes there. The corresponding 'loss' experiment (Fig. 7) showed no

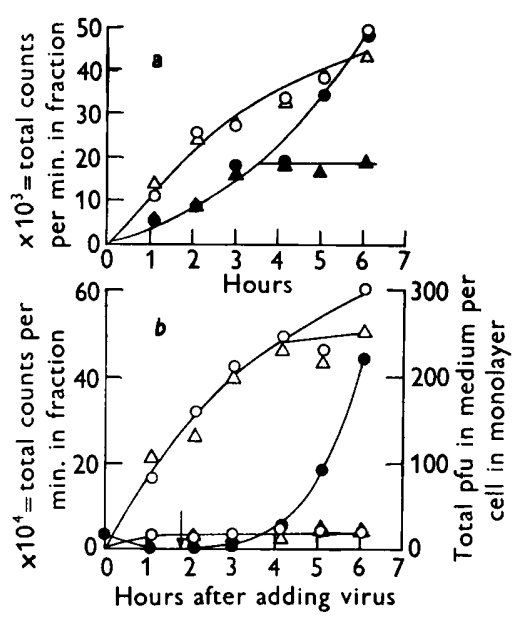

Fig. 6

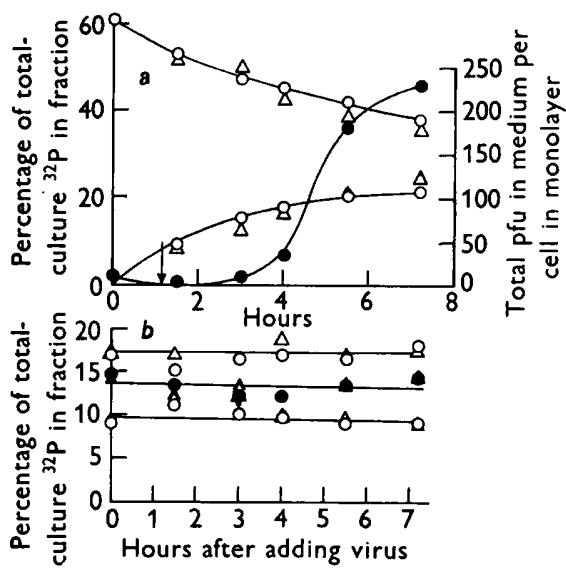

Fig. 7

Fig. 6. A ${ }^{32} \mathrm{P}$ 'gain' experiment followed by cell fractionation by homogenization in Ca-free $0 \cdot 25 \mathrm{M}$-sucrose. Circles represent control and triangles infected samples. $(a)$ shows 'mitochondria' $(O, \triangle)$ and 'microsomes' $(\mathbf{C}, \Delta)$; (b) shows the sucrose-soluble fraction $(O, \Delta$, upper curve), nuclei $(O, \Delta$, lower curve) and virus release $(\circlearrowleft)$. The arrow indicates the end of the latent period obtained from extrapolation of a logarithmic plot. Multiplicity of adsorption $=5-6$.

Fig. 7. A ${ }^{32} \mathrm{P}$ 'loss' experiment followed by cell fractionation by homogenization in Ca-free $0 \cdot 25 \mathrm{M}$-sucrose. (a) shows the sucrose-soluble fraction $\left(\mathrm{O}, \triangle\right.$, upper curve), ${ }^{32} \mathrm{P}$ release into the medium $(O, \triangle$, lower curve), and virus release $(0)$. (b) shows microsomes $(O, \Delta$, upper curve), mitochondria $(O, \Delta$, lower curve) and nuclei $(\bullet, \Delta)$. Circles represent control and triangles infected samples. The arrow indicates the end of the latent period obtained from extrapolation of a logarithmic plot. Multiplicity of adsorption $=5-6$.

change in nuclei, mitochondria or microsomes, but there was a small drop in the sucrose-soluble fraction and a small increase in the medium during virus release, both barely significant. The $2-3 \%$ more of total ${ }^{32} \mathrm{P}$ regularly found in the medium of infected cells (mostly as inorganic $\mathbf{P}$ ) would be apparent as a loss in the curves for the particulate fractions if it derived from them, but it would be masked if it were from the soluble fraction.

The sucrose- $\mathrm{CaCl}_{2}$ 'loss' experiment is not presented, as no changes occurred in any control or virus fraction (particularly nuclei) up to a release of $135 \mathrm{pfu} /$ cell.

With or without $\mathrm{CaCl}_{2}$, the isolated nuclei were microscopically unchanged by virus release, and the microsomal and mitochondrial pellets after centrifugation were identical with controls. 
Table 3a. Effect of VS infection on the Schmidt-Thannhauser $(S-T){ }^{32} P$ distribution in the fractions obtained by Potter-Elvehjem cell-homogenization in 0.25 M-sucrose

Cells were harvested from 6 control and 6 infected monolayers $7 \mathrm{hr}$. after the initiation of a one-step 'loss' experiment (multiplicity of adsorption $=6 \mathrm{pfu} / \mathrm{cell}$, titre at harvesting $=3.88 \times 10^{8} \mathrm{pfu} / \mathrm{ml}$. or $97 \mathrm{pfu} /$ cell, a typical yield for 3 -times washed monolayers). Figures represent per cent total ${ }^{32} \mathrm{P}$ of culture (medium + cells) present in that fraction for $\mathrm{C}=$ control and $\mathrm{V}=$ virus-treated monolayers. $\mathrm{P}=\frac{(\mathrm{V}-\mathrm{C})}{\mathrm{C}} \times 100$ with $\mathrm{C}$ and $\mathrm{V}$ calculated to 3 decimals.

$\quad$ S-T
Fraction
AI
AO $+\gamma^{\prime} \mathbf{P}$
LP
RNA
PP
LM 7 $^{\prime} \mathbf{P}+\mathbf{P P}$
DNA
$\quad$ Total

S-T

Fraction

AI

$\mathbf{A O}+\mathbf{7}^{\prime} \mathbf{P}$

LP

RNA

PP

LM $7^{\prime} \mathbf{P}+\mathbf{P P}$

DNA

Total

\begin{tabular}{|c|c|c|c|c|c|c|c|c|}
\hline \multicolumn{3}{|c|}{ Nuclei } & \multicolumn{3}{|c|}{ Mitochondria } & \multicolumn{3}{|c|}{ Microsomes } \\
\hline C & $\mathbf{V}$ & $\mathbf{P}$ & C & $\mathbf{V}$ & $\mathbf{P}$ & C & $\mathbf{V}$ & $\mathbf{P}$ \\
\hline $0 \cdot 34$ & $0 \cdot 36$ & $+6 \cdot 76$ & 1.01 & $1 \cdot 11$ & +1 & 0.99 & 0.81 & $18 \cdot 2$ \\
\hline 0.15 & $0 \cdot 15$ & +2 & $0 \cdot 31$ & $0 \cdot 39$ & +2 & $0 \cdot 30$ & $0 \cdot 24$ & $9 \cdot 7$ \\
\hline 0.91 & 0.85 & -5 & $2 \cdot 66$ & $2 \cdot 18$ & -1 & $5 \cdot 48$ & $4 \cdot 82$ & $0 \cdot 2$ \\
\hline $1 \cdot 24$ & $1 \cdot 21$ & -2 & $2 \cdot 24$ & $2 \cdot 18$ & -2 & $5 \cdot 54$ & 4.73 & $-14 \cdot 6$ \\
\hline $0 \cdot 66$ & $0 \cdot 38$ & +3 & $1 \cdot 33$ & $1 \cdot 31$ & $-1 \cdot 40$ & $2 \cdot 50$ & $2 \cdot 02$ & $-19 \cdot 2$ \\
\hline 0.47 & 0.72 & +53.3 & $1 \cdot 36$ & 1.57 & +15.5 & $3 \cdot 36$ & $3 \cdot 71$ & $+10 \cdot 1$ \\
\hline $0 \cdot 24$ & 0.47 & +9.85 & $0 \cdot 16$ & $0 \cdot 39$ & +140 & $0 \cdot 27$ & $0 \cdot 23$ & $-16 \cdot 1$ \\
\hline $\mathbf{3} \cdot \mathbf{3 3}$ & $3 \cdot 78$ & +13.5 & $7 \cdot 79$ & $7 \cdot 76$ & -0.38 & $15 \cdot 9$ & $14 \cdot 5$ & $-8 \cdot 67$ \\
\hline
\end{tabular}

Sucrose-soluble

\begin{tabular}{cc}
\hline $\mathrm{C}$ & $\mathrm{V}$ \\
15.4 & $16 \cdot 8$ \\
$7 \cdot 20^{*}$ & $7 \cdot 23^{*}$ \\
1.53 & $1 \cdot 65$ \\
6.00 & $4 \cdot 22$ \\
2.05 & $1 \cdot 71$ \\
3.67 & $\mathbf{2 . 9 0}$ \\
1.06 & 0.66 \\
34.8 & 33.8
\end{tabular}

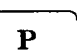

$+8.8937 .0 \quad 38.9$

Medium

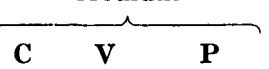

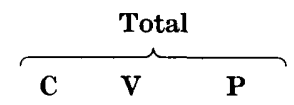

* Not significantly altered after removal of $\gamma^{\prime} \mathbf{P} . \dagger \times 10^{3}=$ total counts per min. in culture.

Table $3 b$. Some relationships between pfu and $L M{ }^{32} P$ in the medium of the experiment described in Table 3 a, after 10 min. centrifugation at 1000 rev./min.

The $\mathrm{LM}^{32} \mathrm{P}$ was separated by precipitation and washings with TCA.

Total counts/min.

$\begin{array}{ccc}\begin{array}{c}\text { in LM }{ }^{32} \mathrm{P} \\ \text { fraction of }\end{array} & \begin{array}{c}\text { Recovery } \\ \text { of pfu } \\ (\%)\end{array} & \begin{array}{c}\text { Recovery } \\ \text { of LM }{ }^{32 P}\end{array} \\ \text { supernatant } & (\%) \\ 504 & 100 & 100 \\ 273 & 63 \cdot 2 & 54 \cdot 2\end{array}$

(1) After $10 \mathrm{~min}$. at $1000 \mathrm{rev} . / \mathrm{min}$.

(2) $100 \mathrm{mg}$. washed infusorial supernatant

$10.2 \times 10^{8}$

earth added to $5 \mathrm{ml}$., stirred

for $5 \mathrm{~min}$. and centrifuged for

$2 \mathrm{~min}$. at $1000 \mathrm{rev} . / \mathrm{min}$.

Supernatant removed for assay

(3) $100 \mathrm{mg}$. fresh infusorial earth added to supernatant, centrifuged $16,000 \mathrm{rev} . / \mathrm{min}$. for $30 \mathrm{~min}$. Supernatant removed for assay

(4) Sediment from (3) resuspended in $5 \mathrm{ml} . \mathrm{ES} / \mathrm{Ox}$, centrifuged $2 \mathrm{~min}$. at $1000 \mathrm{rev} . / \mathrm{min}$. Supernatant removed for assay 
The sucrose-soluble $R N A$ during virus release. The unchanged total particulate ${ }^{32} \mathbf{P}$ (gain or loss) and the just significant changes in sucrose-soluble and Schmidt-Thannhauser ${ }^{32} \mathrm{P}$ (loss) made more information necessary, particularly regarding RNA. For this purpose the cells from six control and six infected monolayers of a 'loss' experiment were removed and pooled $7 \mathrm{hr}$. after infection, fractionated (Potter-Elvehjem) in $\mathbf{0 . 2 5} \mathrm{M}$-sucrose, and the centrifuged products further treated according to Schmidt-Thannhauser. Table $3 a$ shows the ${ }^{32} \mathrm{P}$ content of each fraction. The handling errors are less

Table 4. Distribution of ${ }^{32} \mathrm{P}$ between sucrose-soluble and insoluble fractions after freezing and thawing intact cells and also particulate fractions of cells previously separated by the Potter-Elvehjem method (0.25 M-sucrose)

Cells were harvested and washed after $20 \mathrm{hr}$. incorporation of ${ }^{32} \mathrm{P}$. Each fraction was rapidly frozen in dry ice and allowed to thaw at $30^{\circ}$, then centrifuged for $10 \mathrm{~min}$. at $1000 \mathrm{rev}$./ min. ("slow spin') and the sediment (sucrose-insoluble) washed once in $1 \mathrm{ml}$. sucrose and the supernatants (sucrose-soluble) pooled. Portions of the freeze-thawed cell and mitochondria + microsome fractions were also centrifuged for $1 \mathrm{hr}$. at $25,000 \mathrm{rev} . / \mathrm{min}$. ('fast spin'). ' $\mathbf{T C A}$ ' = two treatments with cold $10 \%$ trichloroacetic acid.

Percentage cellular ${ }^{32} \mathbf{P}$ after freeze-thaw in sucrose

Nature of the fraction to be frozen

Whole cells (slow spin)

Whole cells (fast spin)

Nuclei (slow spin)

Mitochondria (Slow spin + microsomes Fast spin

Sucrose soluble (slow spin)

\begin{tabular}{|c|c|c|c|}
\hline \multicolumn{2}{|c|}{ Sucrose-soluble } & \multicolumn{2}{|c|}{ Sucrose-insoluble } \\
\hline $\begin{array}{c}\text { TCA-soluble } \\
66 \cdot 2\end{array}$ & $\begin{array}{c}\text { TCA-insoluble } \\
\qquad \mathbf{1 5 \cdot 5}\end{array}$ & $\begin{array}{c}\text { TCA-soluble } \\
5 \cdot 5\end{array}$ & $\begin{array}{c}\text { TCA-insoluble } \\
12 \cdot 8\end{array}$ \\
\hline \multicolumn{2}{|c|}{$59 \cdot 9$} & \multicolumn{2}{|c|}{$40 \cdot 1$} \\
\hline $1 \cdot 05$ & $0 \cdot 17$ & $4 \cdot 18$ & $10 \cdot 2$ \\
\hline $\begin{array}{l}6 \cdot 27 \\
2 \cdot 62\end{array}$ & $\begin{array}{r}11 \cdot 24 \\
1 \cdot 68\end{array}$ & $\begin{array}{l}2 \cdot 22 \\
1 \cdot 84\end{array}$ & $\begin{array}{c}6 \cdot 83 \\
19 \cdot 2\end{array}$ \\
\hline $52 \cdot 0$ & $6 \cdot 46$ & $<0.1$ & $<0.1$ \\
\hline
\end{tabular}

than might be expected, as the recoveries of total ${ }^{32} \mathrm{P}$ differed between control and infected cells only by $0.34 \%$. The standard deviations of the ratio of difference between infected and control to control of all the experimental values (excluding 'DNA', which is probably RNA contamination and liable to scatter, and medium LMP, in which the infected is much higher than control) was $17 \cdot 3$ and the mean was $-4 \cdot 3$. This value of the mean close to zero may indicate that, except for 'DNA', no big errors exist. Of the infected RNA fractions, which should show largest virus effects, the biggest change was the drop in sucrose-soluble RNA $(p=0 \cdot 05)$. One cannot be sure of such small differences, however. The bulk of the LMP in the medium after low-speed centrifugation sedimented at the same rate as the pfu (Table $3 b$ ).

In order to confirm this small drop the sucrose-soluble RNA was followed during gain and loss experiments. Cell rupture by one freeze-thaw in sucrose gave a similar soluble fraction (Table 4) to that from Potter-Elvehjem rupture; some extra material may dissolve from subcellular particles, but freezethawing the Potter-Elvehjem soluble fraction made nothing insoluble. The sucrose-soluble fraction was therefore prepared by freezing and thawing the 
intact cells in $0.25 \mathrm{M}$-sucrose for these experiments. Fig. 8 shows a decrease of $\mathbf{3 0 - 5 0} \%$ in the sucrose-soluble RNA in loss and gain experiments, which is probably significant, with the complete halt of ${ }^{32} \mathrm{P}$ uptake during gain also found in most other 'gain' fractions. No early stimulation of uptake occurred.
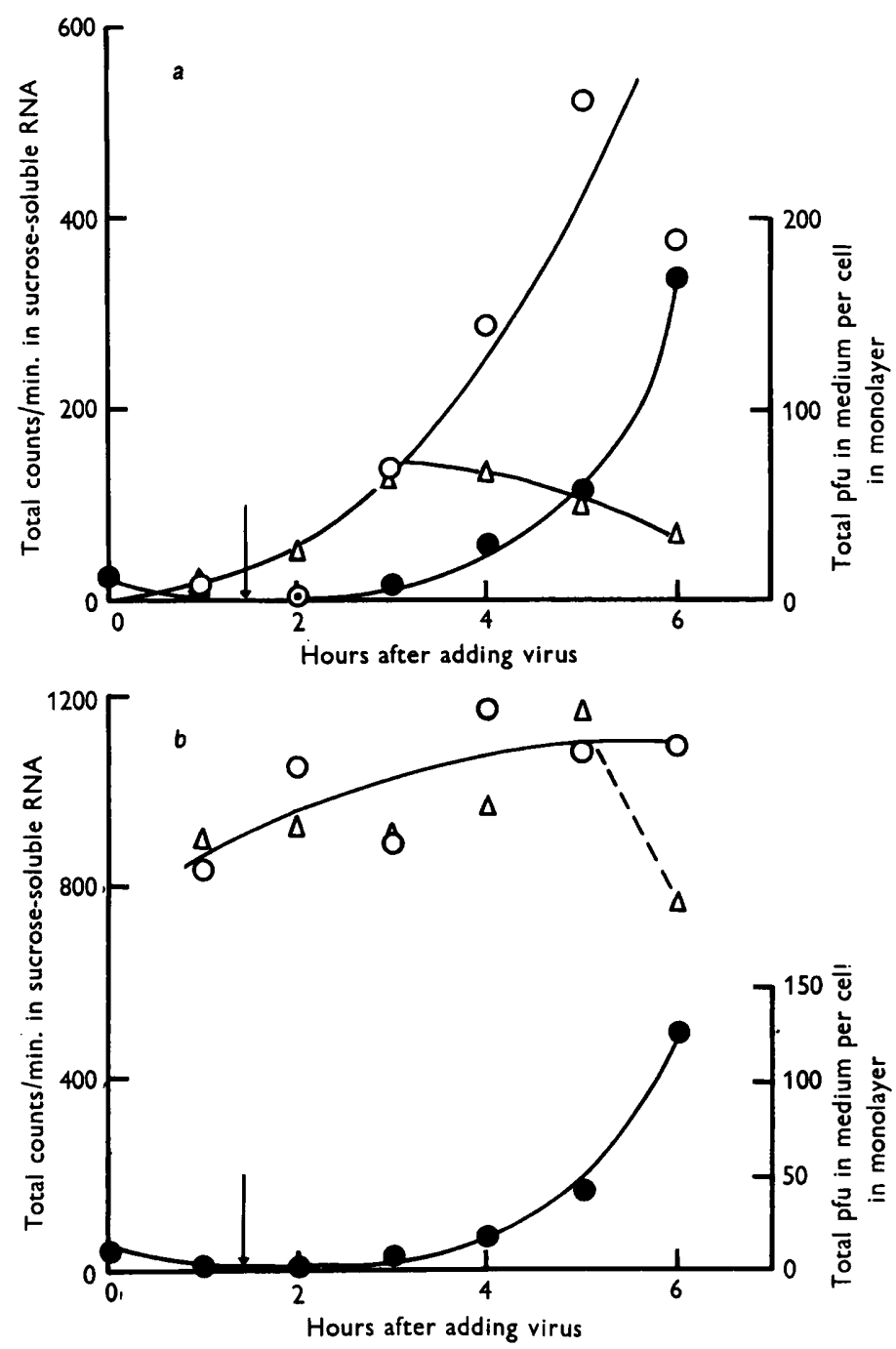

Fig. 8. A 32P 'gain' $(a)$ and a ${ }^{32} \mathbf{P}$ 'loss' $(b)$ experiment performed on the same batch of plates, followed by preparation of the sucrose-soluble fraction by freezing and thawing in $0.25 \mathrm{M}$-sucrose and centrifuging for $1 \mathrm{hr}$. at 25,000 r.p.m. The supernatant was separated by the Schmidt-Thannhauser procedure to obtain alkali-labile acid-insoluble phosphate which was then freed from phospho-protein phosphate and LM $\mathbf{7}^{\prime} \mathbf{P}$. The remainder was assayed as sucrose-soluble RNA ${ }^{32} P(O, \Delta)$, where circles represent control and triangles infected samples. $(O)=$ virus release. The arrows indicate the ends of the latent periods obtained from extrapolations of logarithmic plots. Multiplicity of adsorption $=5-6$. 


\section{DISCUSSION}

The normal phosphate pathways, indicated in outline above, are complex, as may be expected. In general, phosphate entered the cell as inorganic phosphate via the inorganic pool which was in equilibrium with the external medium, and seemed likely to enter RNA in particular via $\mathrm{AO}_{\mathrm{B}}$ rather than direct from $\mathbf{A I}_{\mathrm{R}}$. However, both organic fractions were heterogeneous, and it is not correct to deduce the RNA source without examining individual nucleotides.

The present data do not indicate which nucleic acid fraction was concerned with virus growth. The lack of DNA synthesis in control and infected cells, while virus increased at least as well as in growing cells, may be a useful simplification in that some pathways were but little used; otherwise it indicates that any viral DNA synthesis (equivalent to less than $0.5 \%$ of the DNA of the cells), or conversion of cellular DNA to viral material which was subsequently released, was too small to be detected. The several RNA's appear similar in that no marked stimulation of incorporation was noticeable either in bulk RNA, sucrose-soluble RNA or in the total ${ }^{32} \mathrm{P}$ of the centrifugal fractions, and no loss occurred in any particulate RNA fraction after virus release. The intact appearance of the isolated cell nuclei after virus release indicates that, if growth occurred intranuclearly, then release from the nucleus cannot occur as a 'burst'. The same applies from the chemical data to the intact cell and to all cell particulates.

Nevertheless, certain changes did occur, the significance of which is not immediately apparent. There was a general halt in $\mathbf{P}$ uptake into all fractions (save possibly the mitochondria) soon after 1 pfu was released per infected cell. The small somewhat equivocal decrease in sucrose-soluble RNA P was nevertheless apparent in all experiments designed to show it, and probably represents a lysis as there was a corresponding but barely significant increase in small molecular phosphate. Its appearance as RNA in any other fraction, including the medium, would have been apparent. The significance of this for virus growth may be slight, however, as it is pointed out (Cooper, 1957 a) that, due to the effect of multiplicity of infection on latent period, a small proportion of the cell population will be at a considerably more advanced stage of viral development than the average. This small lysis may therefore represent the first stage of degeneration in this minority. A probably more significant finding is the presence of RNA ${ }^{32} \mathrm{P}$ in the medium which is adsorbed to infusorial earth and centrifuges at the same rate as the pfu. Some rearrangements of the cellular ribonucleotide ratios have been found during VS infection of chick cells (Dr G. L. Turco, personal communication).

Clearly more data is required to interpret these findings. The fact that the total $\mathbf{P}$ content of the matured infective virus must be small compared with the whole cell need not necessarily lead us to expect small changes in the cell. It is necessary to know among other things whether the latent period involves quiescent organization or vigorous viral growth, whether the virus particle contains DNA or RNA and how much, what is the ratio of active to 
inactive particles in the final yield, and which fraction is entered by invading virus nucleic acid. Such information would then guide the more detailed chemical work required to disentangle the small changes incurred by virus action in this system.

It is a question for further work as to whether a cell-virus system showing bigger changes is necessarily a better model for examination, since such changes may be non-specific, and may serve only to obscure changes relevant to virus synthesis.

I am very grateful to my colleagues at the California Institute for stimulating discussions, in particular to Dr R. Dulbecco and Dr G. W. Beadle, and to the Gosney Fund Board of Trustees, the American Cancer Society Inc., and the American Cancer Society, California Division, for financial support as a Research Fellow. I am indebted to the Wright-Fleming Institute of Microbiology, St Mary's Hospital, London, for leave-of-absence.

\section{REFERENCES}

COOPER, P. D. (1957a). Some characteristics of vesicular stomatitis virus growthcurves in tissue culture. J. gen. Microbiol. 17, 327.

Cooper, P. D. (1957b). An osmotic barrier for inorganic phosphate in chick embryo cells and its stability during the latent and release periods of infection by vesicular stomatitis virus. J. gen. Microbiol. 17, 353.

Davidson, J. N., Frazer, S. C. \& Hutchison, W. C. (1949). Phosphorus compounds in the cell. 1. Protein-bound phosphorus fractions studied with the aid of radioactive phosphorus. Biochem. J. 49, 311.

Davidson, J. N. \& Smellie, R. M. S. (1952). Phosphorus compounds in the cell. 2. The separation by ionophoresis on paper of the constituent nucleotides of ribonucleic acid. Biochem. J. 52, 594.

Fiske, C. H. \& SubBarow, Y. (1925). The colorimetric determination of phosphorus. J. biol. Chem. 66, 375.

Hogeboom, G. H., Schneider, W. C. \& Striebich, M. J. (1953). Localisation and integration of cellular function. Cancer Res. 13, 617.

Katchman, B. J. \& Fetty, W. O. (1955). Phosphorus metabolism in growing cultures of $S$. cerevisiae. J. Bact. 69, 607.

Laird, A. K., Nygaard, O., Ris, H. \& Barton, A. D. (1953). Separation of mitochondria into two morphologically and biochemically distinct types. Exp. Cell Res. 5, 147.

Mrtcheld, P. \& Moyle, J. (1953). Paths of phosphate transfer in M. pyogenes: phosphate turnover in nucleic acids and other fractions. J. gen. Microbiol. 9, 257.

Novikoff, A. B., Podber, E., Ryan, J. \& Noe, E. (1953). Biochemical heterogeneity of cytoplasmic particles isolated from rat liver homogenates. $J$. Histochem. Cytochem. 1, 27.

Sanford, K. K., Earle, W. R., Evans, V. J., Waltz, H. K. \& Shannon, J. E. (1951). The measurement of proliferation in tissue culture by enumeration of cell nuclei. J. nat. Cancer Inst. 11, 773.

(Received 28 February 1957) 